\title{
73. Chemical Effects of A- and B-Decomposing Enzymes on Blood Group Substances from Red Cells
}

\author{
By Keiichi Fujisawa, Ken Furukawa, and Shoei Iseki \\ Department of Legal Medicine, School of Medicine, \\ Gunma University, Maebashi \\ (Comm. by Tanemoto Furuhata, M.J.A., May 11, 1963)
}

Activity of blood group substance of red cells has been considered to be present in lipid fraction. However, Kossjakow ${ }^{1)}$ assumed it to be present in polysaccharide fraction, on the other hand Yamakawa and Iida ${ }^{2)}$ claimed it to be found in glycolipid designated as globoside, consisting of fatty acid, sphingosine, acetylchondrosamine, D-galactose, and D-glucose. Yamakawa et al. ${ }^{3)}$ recognized glucosamine in globoside besides the sugars described above, and Yamakawa and Irie ${ }^{4)}$ reported that in group A substance, obtained from red cells, was found mucolipid, which contained sialic acid besides hexose and hexosamine. Also Radin ${ }^{5}$ noted $\mathrm{A}$ and $\mathrm{B}$ activity presumably in glycolipid, extracted from dried red cells. Hakomori and Jeanloz, ${ }^{6}$ who obtained glycolipids, having $\mathrm{A}$ and $\mathrm{B}$ activity, assumed that difference between $A$ and $B$ is based on the mode of attachment of one unit of galactosamine. Kirita ${ }^{\text {r) }}$ found the presence of large amount of fucose in glycolipid from $\mathrm{O}$ red cells. Also Koscielak and Zakrzewski ${ }^{8)}$ noted the presence of fucose in $\mathrm{A}, \mathrm{B}$, and $\mathrm{O}$ blood group substances from red cells, but could not detect $\mathrm{O}(\mathrm{H})$ activity even in substance from $\mathrm{O}$ red cells. Ludewig.9 clarified that carbohydrate of human red cell stroma contained galactose, glucose, mannose, sialic acid, and a small amount of fucose.

As to action of the enzyme on $A$ and $B$ substance from red cells, Morgan $^{10)}$ reported that an enzyme from Clostridium welchii exerted no action on red cells, but acted on blood group substance of red cell stroma, especially on that of group $O$ to abolish its blood group activity. Iseki and $\mathrm{Masaki}^{11)}$ reported that A-decomposing enzyme from Clostridium tertium, acting on carbohydrate-like substance of A red cells, caused depression of A activity and enhancement of $\mathrm{O}(\mathrm{H})$ activity. Howe et $a .^{12)}$ recognized that this enzyme abolished A antigen of red cells. And according to Iseki and Furukawa, ${ }^{13}$ Adecomposing enzyme from Clostridium tertium and B-decomposing enzyme from Clostridium maebashi, acting on A and B red cells, caused conversions of blood group activity from $A$ into $\mathrm{O}(\mathrm{H})$ and from $\mathrm{B}$ into $\mathrm{O}(\mathrm{H})$, respectively.

This report deals with chemical effects of A-decomposing enzyme 
from $C l$. tertium and B-decomposing enzyme from $C l$. maebashi on red cells and blood group active substances derived from them.

Materials and methods. 1) Stroma. Ten volumes of $0.3 \%$ acetic acid was added to red cells and after allowing to stand overnight, the sediment was collected. 2) Crude glycolipid. Prepared by the method of Yamakawa et al. ${ }^{2}$ 3) Sugar constituents. Test material was hydrolyzed with $2 \mathrm{~N}$ sulphuric acid at $100^{\circ} \mathrm{C}$ for 45 minutes, neutralized with barium hydroxide, and concentrated to be subjected to qualitative and quantitative determination of sugars by routine methods.

Results. 1. Constituent sugars. Sugars in red cells, stroma, and crude glycolipid of $\mathrm{A}, \mathrm{B}$, and $\mathrm{O}$ blood groups consisted of hexose, hexosamine, methylpentose and sialic acid, and as hexose were demonstrated galactose, glucose and mannose, as methylpentose, fucose, and as hexosamine, galactosamine and glucosamine. Amount of fucose for stroma was 25-35\% lower than that for red cells, and that for glycolipid 96-98\% lower.

Table I. Serological changes affected by A- and B-decomposing enzyme, of blood group substances from red cells

(Agglutination inhibition test)

\begin{tabular}{|c|c|c|c|c|c|c|c|}
\hline \multirow{2}{*}{$\begin{array}{l}\text { Blood group } \\
\text { substance }\end{array}$} & \multirow{2}{*}{ Antiserum } & \multirow{2}{*}{$\begin{array}{l}\text { Enzyme } \\
\text { action }\end{array}$} & \multicolumn{5}{|c|}{ Antigen dilution } \\
\hline & & & 2 & 4 & 8 & 16 & 32 \\
\hline \multirow{2}{*}{$\begin{array}{l}\text { A red cells } \\
50 \%(\mathrm{v} / \mathrm{v})\end{array}$} & $\begin{array}{l}\text { Anti-A } \\
\text { human serum }\end{array}$ & $\begin{array}{l}\text { Before } \\
\text { After }\end{array}$ & $\overline{+}$ & $\overline{+}$ & $\overline{+}$ & $\bar{t}$ & $\stackrel{+}{+}$ \\
\hline & $\begin{array}{l}\text { Anti-O }(\mathrm{H}) \\
\quad \text { eel serum }\end{array}$ & $\begin{array}{l}\text { Before } \\
\text { After }\end{array}$ & $\underline{-}$ & $\overline{-}$ & \pm & $\underline{+}$ & + \\
\hline \multirow{2}{*}{$\begin{array}{l}\text { A stroma } \\
10 \%(\mathrm{w} / \mathrm{v})\end{array}$} & $\begin{array}{l}\text { Anti-A } \\
\text { human serum }\end{array}$ & $\begin{array}{l}\text { Before } \\
\text { After }\end{array}$ & $\bar{t}$ & $\overline{+}$ & $\overline{+}$ & $\overline{+}$ & $\begin{array}{l}+ \\
+\end{array}$ \\
\hline & $\begin{array}{l}\text { Anti-O }(\mathrm{H}) \\
\quad \text { eel serum }\end{array}$ & $\begin{array}{l}\text { Before } \\
\text { After }\end{array}$ & - & \pm & + & + & + \\
\hline \multirow{2}{*}{$\begin{array}{l}\text { A glycolipid } \\
0.4 \%(\mathrm{w} / \mathrm{v})\end{array}$} & $\begin{array}{l}\text { Anti-A } \\
\text { human serum }\end{array}$ & $\begin{array}{l}\text { Before } \\
\text { After }\end{array}$ & $\overline{+}$ & $\overline{+}$ & $\overline{+}$ & $\overline{+}$ & + \\
\hline & $\begin{array}{l}\text { Anti-O }(\mathrm{H}) \\
\text { eel serum }\end{array}$ & $\begin{array}{l}\text { Before } \\
\text { After }\end{array}$ & \pm & $\begin{array}{l}+ \\
\pm\end{array}$ & + & + & + \\
\hline \multirow{2}{*}{$\begin{array}{l}\mathrm{B} \underset{50 \%(\mathrm{v} / \mathrm{v})}{\mathrm{red}} \text { cells } \\
\end{array}$} & $\begin{array}{l}\text { Anti-B } \\
\text { human serum }\end{array}$ & $\begin{array}{l}\text { Before } \\
\text { After }\end{array}$ & $\bar{t}$ & $\overline{+}$ & $\bar{t}$ & $\overline{+}$ & $\dot{+}$ \\
\hline & $\begin{array}{l}\text { Anti-O }(\mathrm{H}) \\
\quad \text { eel serum }\end{array}$ & $\begin{array}{l}\text { Before } \\
\text { After }\end{array}$ & - & - & \pm & \pm & $\begin{array}{l}+ \\
+\end{array}$ \\
\hline \multirow{2}{*}{$\begin{array}{l}\text { B stroma } \\
2.5 \%(\mathrm{w} / \mathrm{v})\end{array}$} & $\begin{array}{l}\text { Anti-B } \\
\text { human serum }\end{array}$ & $\begin{array}{l}\text { Before } \\
\text { After }\end{array}$ & $\bar{t}$ & $\overline{+}$ & $\bar{t}$ & $\begin{array}{l}+ \\
+\end{array}$ & $\begin{array}{l}+ \\
+\end{array}$ \\
\hline & $\begin{array}{l}\text { Anti-O }(\mathrm{H}) \\
\quad \text { eel serum }\end{array}$ & $\begin{array}{l}\text { Before } \\
\text { After }\end{array}$ & $\overline{-}$ & \pm & + & + & $\begin{array}{l}+ \\
+\end{array}$ \\
\hline \multirow{2}{*}{$\begin{array}{l}\text { B glycolipid } \\
0.65 \%(\mathrm{w} / \mathrm{v})\end{array}$} & $\begin{array}{l}\text { Anti-B } \\
\text { human serum }\end{array}$ & $\begin{array}{l}\text { Before } \\
\text { After }\end{array}$ & $\bar{t}$ & $\overline{+}$ & $\overline{+}$ & $\bar{t}$ & + \\
\hline & $\begin{array}{l}\text { Anti- } \mathrm{O}(\mathrm{H}) \\
\quad \text { eel serum }\end{array}$ & $\begin{array}{l}\text { Before } \\
\text { After }\end{array}$ & $\overline{-}$ & \pm & $\begin{array}{l}+ \\
+\end{array}$ & $\begin{array}{l}+ \\
+\end{array}$ & $\begin{array}{l}+ \\
+\end{array}$ \\
\hline
\end{tabular}


2. Changes in specific activity of blood group substances from red cells induced by enzyme. The A- and B-decomposing enzymes were respectively applied to A and B substance from red cells, and these were investigated for changes in the blood group specificity. The results are shown in Table I.

In crude glycolipids of groups $\mathrm{A}$ and $\mathrm{B}$ were respectively recognized $\mathrm{A}$ and $\mathrm{B}$ activity, but $\mathrm{O}(\mathrm{H})$ activity, reacting with anti- $\mathrm{O}(\mathrm{H})$ eel serum, was extremely low. When the A- and B-decomposing enzymes were applied to A and B red cells, stroma and glycolipid, respectively, $\mathrm{A}$ and $\mathrm{B}$ activity diminished while $\mathrm{O}(\mathrm{H})$ activity to react with anti$\mathrm{O}(\mathrm{H})$ eel serum was enhanced, though less weakly in stroma and glycolipid than in red cells.

3. Chemical changes in blood group substances of red cells induced by enzyme. When the A- and B-decomposing enzymes were respectively applied to $\mathrm{A}$ and $\mathrm{B}$ blood group substance of red cells, the results as shown in Table II were obtained.

Table II. Chemical changes induced by A- and B-decomposing enzyme, of blood group substances of red cells

\begin{tabular}{|c|c|c|c|c|c|}
\hline $\begin{array}{l}\text { Blood group } \\
\text { substance }\end{array}$ & $\begin{array}{l}\text { Enzyme } \\
\text { action }\end{array}$ & & $\begin{array}{c}\text { Hexose } \\
\text { (as galactose) }\end{array}$ & $\begin{array}{l}\text { Methylpentose } \\
\text { (as fucose) }\end{array}$ & $\begin{array}{c}\text { Hexosamine } \\
\text { (as galactosamine) }\end{array}$ \\
\hline \multirow{3}{*}{$\begin{array}{l}\mathrm{A}_{1} \underset{(50 \mathrm{ml})}{\text { red cells }} \\
\quad\end{array}$} & \multicolumn{2}{|l|}{ Before } & $5340 \mu \mathrm{g}$ & $1305 \mu \mathrm{g}$ & $2672 \mu \mathrm{g}$ \\
\hline & \multirow{2}{*}{\multicolumn{2}{|c|}{ After }} & 2833 & 0 & 1080 \\
\hline & & & 2510 & 1300 & 1590 \\
\hline \multirow{3}{*}{$\begin{array}{l}\text { A glycolipid } \\
(40 \mathrm{mg})\end{array}$} & \multicolumn{2}{|l|}{ Before } & 660 & 122 & 383 \\
\hline & \multirow{2}{*}{ After } & DP & 547 & 0 & 229 \\
\hline & & NP & 116 & 124 & 92 \\
\hline \multirow{3}{*}{$\begin{array}{l}B \text { red cells } \\
(50 \mathrm{ml})\end{array}$} & \multicolumn{2}{|l|}{ Before } & 4008 & 1816 & 2840 \\
\hline & \multirow{2}{*}{ After } & DP & 2074 & 0 & 0 \\
\hline & & NP & 1920 & 1820 & 2820 \\
\hline \multirow{3}{*}{$\begin{array}{l}\text { B glycolipid } \\
\text { (65 mg) }\end{array}$} & Before & & 670 & 97 & 518 \\
\hline & \multirow{2}{*}{ After } & $\mathrm{DP}$ & 515 & 0 & 0 \\
\hline & & NP & 160 & 96 & 520 \\
\hline
\end{tabular}

$\mathrm{DP}$, dialyzable portion; NP, non-dialyzable portion.

In an incubation of $1 \mathrm{~g}$ of the A-decomposing enzyme preparation with $50 \mathrm{ml}$ of $\mathrm{A}_{1}$ red cells, about $45 \%$ of total amount of sugar was liberated, which was consisted of about $50 \%$ of original amount of hexose, and about $40 \%$ of original amount of hexosamine. As hexose was demonstrated galactose, and as hexosamine was demonstrated $\mathrm{N}$-acetylgalactosamine as simple sugar. Besides these were found sialic acid with $R_{\text {galactose }}$ value of 0.33 and a $1 \rightarrow 3$ (or $1 \rightarrow 6$ ) linked disaccharide with $\mathrm{R}_{\text {galactose }}$ value of 0.71 , consisting of $\mathrm{N}$-acetyl- 
galactosamine and galactose.

In an incubation of $500 \mathrm{mg}$ of the A-decomposing enzyme preparation with $40 \mathrm{mg}$ of crude glycolipid from A red cells, about $74 \%$ of total amount of sugar was liberated, which was composed of about $82.5 \%$ of original amount of hexose, and about $60 \%$ of original amount of hexosamine. As hexose was demonstrated galactose, and as hexosamine was demonstrated $N$-acetylgalactosamine. Besides these were found assumedly sialic acid with $R_{\text {galactose }}$ value of 0.345 and a $1 \rightarrow 3$ (or $1 \rightarrow 6$ ) linked disaccharide with $R_{\text {galactose }}$ value of 0.76 , consisting of $\mathrm{N}$-acetylgalactosamine and galactose, and an oligosaccharide with $\mathrm{R}_{\text {galactose }}$ value of 0.505 , consisting of $N$-acetylgalactosamine and galactose.

When $1 \mathrm{~g}$ of the B-decomposing enzyme preparation was applied to $50 \mathrm{ml}$ of $\mathrm{B}$ red cells, about $24 \%$ of total amount of sugar was liberated, all of which was galactose, estimated at about $51 \%$ of original amount of hexose. When $1 \mathrm{~g}$ of the B-decomposing enzyme was applied to $65 \mathrm{mg}$ of crude glycolipid from B red cells, about $40 \%$ of total amount of sugar was liberated, all of which was occupied by galactose, calculated at about $77 \%$ of original amount of hexose.

When either the A- or B-decomposing enzyme was applied to $\mathrm{A}_{1} \mathrm{~B}$ red cells, $\mathrm{O}(\mathrm{H})$ activity was enhanced. The chemical effects in these cases were approximately the same with those described above.

Discussion. In the digestion by A-decomposing enzyme, of $\mathrm{A}$ red cells or of crude glycolipid derived from them, there were liberated not only galactose but also $N$-acetylgalactosamine, the end determinant of the A specificity, and oligosaccharide, consisting of $\mathrm{N}$-acetylgalactosamine and galactose with assumedly $1 \rightarrow 3$ linkage. As the result of application of the A-decomposing enzyme, 1,080 $\mu \mathrm{g}$ of galactosamine was liberated from $50 \mathrm{ml}$ of $A_{1}$ red cells. From this result, molecule number of this determinant of A specificity per one red cell is computed at about 7,300,000, using Avogadro number, and taking number of red cells per $1 \mathrm{~mm}^{3}$ as $10,000,000$. This value is approximate to the number of combining sites of one A red cell, which was estimated by Boyd et al. ${ }^{14)}$ to be 8 or 10 million from the combining capacity to anti-A agglutinin from Sieva lima bean.

When the B-decomposing enzyme was applied to B red cells or crude glycolipid from these, galactose, the determinant of the $B$ specificity, was liberated. And in this way, from $50 \mathrm{ml}$ of $\mathrm{B}$ red cells was obtained 2,074 $\mu \mathrm{g}$ of galactose. Molecule number of this determinant of the $\mathrm{B}$ specificity per one red cell is computed at about 14,000,000, applying an equation described above. And if the determinant of the $\mathrm{B}$ specificity in red cells is $\alpha$-D-galactopyranosyl-(1 $\rightarrow 3)$ - 
D-galactose, which result was obtained by Painter et al. ${ }^{15)}$ from watersoluble blood group substance, and if the B-decomposing enzyme liberates a disaccharide consisted of two-molecular galactose, then molecule number of galactose as the terminal determinant of the $\mathrm{B}$ specificity will be about 7,000,000. The value, however, is considerably larger as compared with the number of combining sites of one $\mathrm{B}$ red cell, which was estimated by Wurmser et al. ${ }^{16)}$ to be 500,000 from the combining capacity to human anti-B agglutinin. Similarly, molecule number per one $A_{1} B$ red cell of galactosamine as the terminal determinant of A specificity was computed from $167 \mu \mathrm{g}$ of this sugar, liberated from $15 \mathrm{ml}$ of $\mathrm{A}_{1} \mathrm{~B}$ red cells by the action of the A-decomposing enzyme, at about 3,770,000. Further from $391 \mu \mathrm{g}$ of galactose, liberated from $15 \mathrm{ml}$ of $\mathrm{A}_{1} \mathrm{~B}$ red cells by the action of the B-decomposing enzyme, molecule number of galactose as the end determinant of the B specificity was computed to be about $4,400,000$.

Summary. 1. Sugars in red cells, stroma, and crude glycolipid of $\mathrm{A}, \mathrm{B}$, and $\mathrm{O}$ blood groups consisted of galactose, glucose, mannose, fucose, $N$-acetylgalactosamine, $N$-acetylglucosamine, and sialic acid.

2. When the blood group specific enzyme was applied to red cells or crude glycolipid derived from them, disaccharide, consisting of $N$-acetylgalactosamine and galactose, was mainly demonstrated besides such monosaccharides as $N$-acetylgalactosamine and galactose in the case of group $\mathrm{A}$, and monosaccharide, galactose, in the case of group B.

3. From the amount of sugar liberated from red cells as the result of the enzyme action, molecule number of sugar as the end determinant of the blood group specificity per one red cell was calculated.

\section{References}

1) Kossjakow, P. N.: Polysaccharide-Träger der Gruppeneigenschaften des Menschen, Ztschr. f. Immunitätsf., 99(3), 221-231 (1941).

2) Yamakawa, T., and Iida, T.: Immunochemical study on the red blood cells. 1 . Globoside, as the agglutinogen of the ABO system on erythrocytes, Japan. J. Exp. Med., 23(4), 327-331 (1953).

3) Yamakawa, T., Matsumoto, M., Suzuki, S., and Iida, T.: The chemistry of the lipids of posthemolytic residue or stroma of erythrocytes. VI. Sphingolipids of erythrocytes with respect to blood group activities, J. Biochem., 43(1), 41-52 (1956).

4) Yamakawa, T., and Irie, R.: On the mucolipid nature of ABO-group substance of erythrocytes, J. Biochem., 48(6), 919-920 (1960).

5) Radin, N. S.: Glycolipide chromatography, Fed. Proc., 16, 825-826 (1957).

6) Hakomori, S., and Jeanloz, R. W.: Isolation and characterization of glycolipids from erythrocytes of human blood $\mathrm{A}$ (plus) and B(plus), J. Biol. Chem., 236(11), 2827-2834 (1961). 
7) Kirita, K.: Blood group substances from human erythrocytes (in Jap.), Hanzaigaku Zasshi, 26(5-6), 163-172 (1960).

8) Koscielak, J., and Zakrzewski, K.: Blood group substances (A, B, and O) from red cells, Intern. Sym. Biol. Active Mucoids, Warsaw, Poland, p. 21-28 (1960).

9) Ludewig, S.: Carbohydrate constituents of human red cell stroma, Proc. Soc. Exp. Biol. and Med., 104(2), 250-252 (1960).

10) Morgan, W. T. J.: The human ABO blood group substances, Experientia, 3(7), 257267 (1947).

11) Iseki, S., and Masaki, S.: Transformation of blood group substance by bacterial enzyme, Proc. Japan Acad., 29(8), 460-465 (1953).

12) Howe, C., MacLennan, J. D., Mandl, I., and Kabat, E. A.: Enzymes of Clostridium tertium. Effects on blood group and virus receptor substances, J. Bact., 74(3), 365-376 (1957).

13) Iseki, S., and Furukawa, K.: On blood group specific decomposing enzymes derived from bacteria, Proc. Japan Acad., 35(10), 620-625 (1959).

14) Boyd, W. C., Bhatia, H. M., Diamond, M. A., and Matsubara, S.: Quantitative study of the combination of lima bean lectin with human erythrocytes, J. Immunol., 89(4), 463-470 (1962).

15) Painter, T. J., Watkins, W. M., and Morgan, W. T. J.: Isolation of a B-specific disaccharide from human blood-group B substance, Nature, 193(4820), 1042-1044 (1962).

16) Filitti-Wurmser, S., Jacquot-Armond, Y., Aubel-Lesure, G., and Wurmser, R.: Physico-chemical study of human isohaemagglutination, Ann. Eugenics, 18(2), 183-202 (1954). 